\title{
REVIEW OF INDONESIA'S EMPLOYMENT ARRANGEMENTS IN FACING ASEAN ECONOMIC COMMUNITY
}

\author{
Ayu Permatasari ${ }^{1}$, Chatrina Febriani Pratiwi ${ }^{2}$, Medika Era Wijaya ${ }^{3}$ \\ ${ }^{1}$ Faculty of Law, Universitas Lampung, Indonesia, \\ E-mail: ayupermatasariat@gmail.com \\ ${ }^{2}$ Faculty of Law, Universitas Lampung, Indonesia, \\ E-mail: pratiwichatrina@gmail.com \\ ${ }^{3}$ Faculty of Law, Universitas Lampung, Indonesia, \\ E-mail: medikaerawijaya1010@gmail.com
}

Submitted: June 15, 2021; Reviewed: July 9, 2021; Accepted: August 12, 2021

\begin{tabular}{|c|c|}
\hline Article Info & Abstract \\
\hline $\begin{array}{l}\text { Keywords: } \\
\text { Overview, Employment } \\
\text { Arrangements, AEC. }\end{array}$ & $\begin{array}{l}\text { The AEC is the founder of the ASEAN Community and the } \\
\text { formation of regional economic integration, which was } \\
\text { implemented in 2015. The implementation of ASEAN is made up } \\
\text { of the flow of services/goods on a single product and market basis, }\end{array}$ \\
\hline $\begin{array}{l}\text { DOI: } \\
\text { 10.25041/lajil.v3i2.2365 }\end{array}$ & $\begin{array}{l}\text { skilled labour, investment, and free capital flows between } \\
\text { countries in the ASEAN region. As an opportunity at the time of } \\
\text { employment and as a substitute for unemployment, the Indonesian } \\
\text { state must be utilized free of skilled labour. The issues that have } \\
\text { arisen are how the employment arrangements in Indonesia are? } \\
\text { How to optimize Indonesia's employment arrangements in the } \\
\text { AEC era? The method of approaching this research is the } \\
\text { normative juridical method. The research shows that there are } \\
\text { arrangements in the field of manpower that help realize quality } \\
\text { human resources and skilled labour. It also states that Law No. } 13 \\
\text { of } 2003 \text { on Manpower and other policies that provide job training } \\
\text { and certification of work competencies that optimize employment } \\
\text { to be more qualified, skilled, and competitive and recognized by } \\
\text { other ASEAN countries in facing the AEC. }\end{array}$ \\
\hline
\end{tabular}

\section{A. Introduction}

According to Law No. 13 of 2003 concerning Manpower, anyone can do work to produce goods or services to meet their own needs and those of the community. Human resources are services/work provided to the production system. Human resources can also provide quality in business to people within a particular time to obtain goods or services, and human resources link someone who can work to be given a working business/service. Able to work is someone who can carry out activities that have economic value, for example, activities that can obtain goods or services to fulfill the needs of people's lives. Human resources consist of employees and labourers who can produce services and work for other parties, namely the government, state companies, and private companies. The definition of Human Resources (HR) contains aspects of quality in the work services provided to produce and aspects of quantity in the 
number of people who can work. ${ }^{1}$ The quality human resources are expected to produce products capable of competing in the ASEAN market. ${ }^{2}$

The ASEAN Economic Community (AEC) is an achievement of the target in 2015 and has already started its implementation in regional economic integration. As a result of its accomplishment, ASEAN can become a single base and single market where there has been a flow of goods or services, skilled labour, and free capital and investment flows. ASEAN is also expected to decrease the increase in economic factors and differences in socio-economics in the ASEAN region. As much as possible can be utilized in the formation of regional economic integration. The integration of the ASEAN economic region would have some legal consequences, and the business as an actor or business people coming from different countries, which would undoubtedly have some differences. ${ }^{3}$ Considering that Indonesia is the largest in ASEAN, which has an area and geographical location, population size, and GDP value, it can be an asset for Indonesia to become a significant player in the AEC. ${ }^{4}$

In particular, the Southeast Asian region is experiencing a crisis in the economy. In October 2003 was known as the Bali Concord-II when it was declared in Bali. Then in commemoration of the $40^{\text {th }}$ anniversary of the founding of ASEAN, the establishment of regional cooperation was further strengthened by being signed by the ASEAN Charter. The ASEAN charter's conventions and signings aim to integrate the region, informing the ASEAN community and intensifying the formation of communities by increasing cooperation. Coinciding with the signing of the ASEAN Charter, the blueprint is a guide for the AEC. It tends to encourage ASEAN heads of state to agree to establish an ASEAN Community in the fields of the ASEAN Economic Community, ASEAN Socio-Cultural, and Political Security. The blueprint consists of four pillars: (i) a single market and production base; (ii) a highly competitive economic region; (iii) an economically equitable region; and (iv) a region fully integrated into the global economy. Economic measures to advance ASEAN's goal of establishing an AEC are included in each pillar. ${ }^{5}$ Strategic schedule regarding the stages and time of achievement between each pillar that has been agreed. ${ }^{6}$

In 2015, ASEAN member countries agreed to the 2025 ASEAN Economic Community Blueprint. The 2025 AEC Blueprint will build on the 2015 AEC Blueprint, which consists of five interrelated and mutually reinforcing characteristics, namely: ${ }^{7}$

(a) a unified and fully integrated economy;

(b) a competitive, innovative, and dynamic ASEAN;

(c) Improved sectoral connectivity and cooperation;

(d) a resilient, inclusive, people-oriented, and people-centered ASEAN; and

(e) Global ASEAN.

\footnotetext{
1 Anditya Putra, "Implementasi Kebijakan Ketenagakerjaan Di Kabupaten Sumedang," Prosiding Penelitian Dan Pengabdian Kepada Masyarakat 2, no. 3 (2015), https://doi.org/10.24198/jppm.v2i3.13595.

2 Tobari, Muhammad Kristiawan, and Nova Asvio, "The Strategy Of Headmaster On Upgrading Educational Quality In Asean Economic Community (AEC) Era," International Journal of Scientific \& Technology Research 7, no. 4 (2018): 72.

3 Sahlan, "Preparation of International Business Contracts in Facing the ASEAN Economic Community Era," Hasanuddin Law Review 2, no. 3 (2016): 426, https://doi.org/10.20956/halrev.v2i3.702.

${ }^{4}$ Rian Destiningsih, "Pengaruh Sektor Industri Terhadap Peningkatan Tenaga Kerja Di Kabupaten Magelang," Jurnal Humaniora: Jurnal Ilmu Sosial, Ekonomi Dan Hukum 4, no. 2 (2020), https://doi.org/10.30601/humaniora.v4i2.1070.

${ }^{5}$ Deunden Nikomborirak, "The ASEAN Economic Community (AEC): Myths and Realities," Asian Economic Papers 14, no. 2 (2015): 73, https://doi.org/10.1162/ASEP_a_00348.

${ }^{6}$ Husnayetti, "Masyarakat Ekonomi Asean 2015 Dan Daya Saing Sumber Daya Manusia," Jurnal Liquidity 3, no. 2 (2014), https://doi.org/10.32546/lq.v3i2.94.

7 Setyani Agung Dwi Astuti, “Dampak Covid-19 Terhadap Ketenagakerjaan Dan UMKM Di Mojokerto,” Jurnal Inovasi Penelitian 1, no. 9 (2021), https://doi.org/10.47492/jip.v1i9.236.
} 
As of December 31, 2017, 72 of the 118 priorities (61\%) of AEC implementation have been successfully implemented. Twelve of the 46 unimplemented priorities have been implemented by several ASEAN member countries. So far, Indonesia has implemented 85 of the 118 priorities. $^{8}$ AEC 2025 continues AEC 2015 and aims to make the ASEAN economy more integrated and cohesive; competitive and dynamic; increased connectivity and sectoral cooperation; resilient, inclusive, community-oriented, and centered; and global ASEAN. ${ }^{9}$ Scope of ASEAN economic cooperation: ASEAN economic cooperation covers industry, trade, investment, services and transportation, telecommunications, tourism, and finance. In addition, this cooperation covers the fields of agriculture and forestry, energy and minerals, and micro, small and medium enterprises (MSMEs). We can see the profile of the ASEAN economy as follows:

a. The large population of ASEAN, which is 632 million people (2015), the majority are of productive age;

b. The economic growth of ASEAN countries is relatively high, averaging 5\% - 6\% per year. To encourage equality of development among member countries (narrowing the development gap), ASEAN has the Initiative for ASEAN Integration (IAI). IAI aims to create equitable development between ASEAN-6 (Brunei Darussalam, Indonesia, Malaysia, Philippines, Singapore, and Thailand) and CLMV (Cambodia, Laos, Myanmar, and Vietnam).

c. Implementation of the Initiative for ASEAN Integration: The Initiative for ASEAN Integration is implemented in capacity-building training projects, institutional development assistance, policy advice, and feasibility studies.

d. Initiative for ASEAN Integration project funding: Project implementation generally receives funding from ASEAN-6, dialogue partners, or international institutions within the framework of the IAI as well as bilaterally.

e. Initiative for ASEAN Integration projects: Initially, the Initiative for ASEAN Integration project was implemented in the economic fields such as infrastructure development, human resources, capacity building for regional integration, energy, investment climate, tourism, poverty alleviation, and quality of life improvement. In its development, the IAI project was expanded to cover the political-security and socio-cultural fields.

In addition, based on Indonesia's proposal, ASEAN has approved the ASEAN Framework on Equitable Economic Development (AFEED). The framework puts forward efforts to reduce development gaps, strengthen the quality of human resources, improve social welfare, develop micro, small and medium enterprises (MSMEs), and more involvement in the ASEAN integration process. In general, economic development aims to increase the standard of living and improve the quality of life, which can be interpreted as the degree to which basic needs are met. Without additional employment opportunities, economic growth will result in an unequal distribution of the additional income. The inequality that occurs can create economic growth with an increase in poverty. The economic structure of a country is reflected in, among other things, the employment structure. As the $4^{\text {th }}$ most populous country in the world, Indonesia has a vast workforce. In general, the Indonesian job market is characterized by a very high supply of employment, massive unemployment, and low quality of employment.

Improving the quality of Human Resources, both domestic and foreign workers should receive earnest attention from the private sector and the government. The impact of the implementation of the ASEAN Economic People to compete with workers who can enter

\footnotetext{
${ }^{8}$ Yuliana Yuli, "Regulasi Pendidikan Nasional Sebagai Upaya Meningkatkan Sumber Daya Manusia Memasuki Era Masyarakat Ekonomi Asean (MEA)," Jurnal Yuridis 3, no. 1 (2016), https://doi.org/10.35586/.v3i1.171.

${ }^{9}$ Vivi Regina Haryati, "Implementasi Masyarakat Ekonomi Asean Terhadap Elemen Tenaga Kerja Terdidik Di Indonesia,” Jurnal Ekonomi Pembangunan 17, no. 2 (2019), https://doi.org/10.29259/jep.v17i2.9508.
} 
from abroad. Efforts are needed to do that by improving the quality of human resources of the workforce. The implementation of various policies that have been held in the field of employment is required to be optimized to develop human resources and improve the quality of Indonesia to be able to prepare a skilled workforce. They can compete at the global level, especially in facing the ASEAN Economic People. The implementation of the labour law must be optimized so that it can be used to improve on-the-job training, the formation of a skilled workforce, and the formation of LSPs to compete in the free flow of skilled labour in the face of the AEC.

The problem in this paper is how the employment arrangements in Indonesia are? And how to optimize Indonesia's employment arrangements in the AEC era? The approach method in this research is the normative juridical method. Sources were obtained by using primary data and secondary data. Primary data is obtained from the research results in the field directly, and secondary data is obtained from the research results based on the literature. The data are in the form of library research and field studies.

\section{B. Discussion}

\section{Employment Arrangements in Indonesia}

The welfare state law theory is related to 2 concepts, namely the legal state and the welfare state. The rule of law is a state that occupies the law as the organizer of power and the basis of power in all its forms. At the same time, the concept of a welfare state is a state that is public order and a bearer of responsibility for realizing general welfare, people's prosperity, and social justice. As stated in the 1945 Constitution of the Republic of Indonesia, the Indonesian state aims to reflect the type of welfare state. ${ }^{10}$

To face the challenges of globalization through internal strengthening, Indonesia must improve its quality in human resources that have global competitiveness. The government has a vital role in preparing and dealing with the ASEAN single market in 2015. This agreement is to ensure conducive sustainable development, realize prosperity and decent life, and world prosperity. During the process of forming the ASEAN community, society is at its center. Indonesia is allowed to conduct regional cooperation. The definition of manpower is stated in the "Manpower Law" that manpower includes residents who are already working or who are currently working or someone looking for work and carrying out other jobs. Therefore, in the State of Indonesia, the minimum age limit is 15 years to a maximum of 55 years. ${ }^{11}$ Manpower in Indonesia is regulated in several regulations as follows:

- Law No. 13 of 2003 concerning Manpower

- Law No. 2 of 2004 concerning Settlement of Industrial Relations Disputes

- Law No. 21 of 2000 concerning Trade Unions/Labour Unions

- Law No. 40 of 2004 concerning the Social Security System

- Law No. 39 of 200 concerning the Placement and Protection of Indonesian Migrant Workers Abroad

- Law No. 21 of 2003 concerning Ratification of the ILO Convention No. 81 Concerning Labour Inspection in Industry and Commerce

- Law No. 1 of 2000 concerning Ratification of the ILO Convention No. 182 Concerning the Prohibition and Immediate Action for Elimination of the Worst Forms of Child Labour

${ }^{10}$ Sri Maulidiah, "Administrasi Ketenagakerjaan Di Kota Pekanbaru," Jurnal Publika 1, no. 2 (2015), https://doi.org/10.25299/jiap.2015.vol1(2).1562.

${ }^{11}$ Najmi Ismail, "Hukum Dan Fenomena Ketenagakerjaan," Focus: Jurnal Pekerjaan Sosial 1, no. 3 (2018), https://doi.org/10.24198/focus.v1i3.20494. 
- Law No. 21 of 1999 concerning Ratification of the ILO Convention No. 111 concerning Discrimination in Respect of Employment and Occupation

- Law No. 20 of 1999 Ratification of the ILO Convention No. 138 concerning the Minimum Age for Admission to Employment

- Law No. 19 of 1999 concerning Ratification of the ILO Convention No. 105 concerning the Abolition of Forced Labour

- Government Regulation No. 46 of 2015 concerning the Implementation of the Old Age Security Program

- Government Regulation No. 45 of 2015 concerning the Implementation of the Pension Guarantee Program

- Government Regulation No. 44 of 2015 concerning the Implementation of the Employment Security and Death Security Program

- Government Regulation No. 4 of 2015 concerning the Implementation of Supervision of the Placement and Protection of Indonesian Migrant Workers Abroad

- Presidential Regulation No. 72 of 2014 concerning the Use of Foreign Workers and the Implementation of Education and Training for Companion Workers

- Presidential Regulation No. 111 of 2013 concerning Amendments to Presidential Regulation Number 12 of 2013 concerning Health Insurance

- Presidential Regulation No. 21 of 2010 concerning Labour Inspection

- Presidential Regulation No. 81 of 2006 concerning the National Agency for the Placement and Protection of Workers

- Presidential Regulation No. 64 of 2011 concerning Health and Psychological Examination of Prospective Indonesian Migrant Workers

- Presidential Regulation No. 45 of 2013 concerning the Coordination of the Return of Indonesian Migrant Workers

- Presidential Regulation No.12 of 2013 concerning Health Insurance

The workforce is classified into 2, namely from labour force and non-labour force. The labour force includes the unemployed or someone who is looking for work and who is working. Meanwhile, those not in the labour force include people who are still carrying out other jobs, such as school and taking care of the household. ${ }^{12}$ The impact of the enactment of the ASEAN Economic Community is the free movement of skilled workers between countries, namely the creation of guts to service delivery through reductions or obstacles. It is specific in mode 4 of individual service providers, namely workers from abroad who provide specific skills and then come to their consumer countries.

According to Budiono, a foreign worker is "a person who is not an Indonesian citizen but can work both inside and outside the employment relationship to produce services or goods that meet the community's needs". In this case, foreign workers are included in the skilled workforce. Several professional organizations have signed a Mutual Recognition Arrangement (MRA). ${ }^{13}$ They will provide services to consumer countries in various priority areas in MRA by agreed standards. Workers have the right to receive recognition for their work abilities after participating in vocational training or on-the-job training carried out by training institutions such as government and private vocational training institutions. Recognition of workability is carried out through workability certification. Experienced

\footnotetext{
12 Zulkifli Anshori and I Made Suparta, "Pengaruh Pertumbuhan Ekonomi, Jumlah Angkatan Kerja, Dan Inflasi Terhadap Tingkat Pengangguran Di Provinsi Jawa Timur (2007-2016),” Jurnal Ekonomi \& Bisnis 3, no. 2 (2018): 679, https://doi.org/10.1234/jeb17.v3i02.2129.

${ }^{13}$ Desi Adhariani, Sylvia Veronica Siregar, and Rini Yulius, "Borderless with Unequal Opportunity? Experts' Perspectives on the ASEAN Economic Community and Impact on Indonesian Accountant Profession," The Qualitative Report 24, no. 5 (2019): 1148, https://doi.org/10.46743/2160-3715/2019.3940.
} 
workers can also take a certificate of work competence. An independent national professional certification body has been established to certify work skills.

\section{Optimizing The Indonesian Employment Arrangements in ASEAN Economic Community (AEC) Era}

The establishment of the ASEAN single market opens the greatest opportunity for Indonesia, as long as it can prepare as much as possible for all existing potentials. These potentials are large areas, population, and human resources that are very abundant compared to regions in other countries. Indonesia is a country that has abundant natural resources. Indonesia must prepare itself as much as possible and improve its quality of employment to be utilized domestically and in ASEAN countries. Optimizing employment arrangements in Indonesia in dealing with AEC, namely by implementing policies that are supported in improving the quality of the workforce, must be carried out continuously with the government and the private sector. There are government policies that require the government to prepare and produce quality/skilled workers and the development of human resources, such as the "Labour Law," which requires providing vocational training for workers to improve their skills and qualifications to achieve prosperity in life. One of the crucial forms of optimizing job training is that a person cannot do certain jobs according to the needs of the work specified to increase their productivity. ${ }^{14}$

The Manpower Law is also linear with Government Regulation No. 23 of 2004 concerning National Agency of Profession Certification or Badan National Sertifikasi Profesi (BNSP), which requires the establishment of a BNSP. BNSP is independent and responsible for the certification of the workability of the president's executives. According to Article 4 of Government Regulation No. 23 of 2004, to carry out the task of certifying work skills, the national professional certification body can grant permits to Profession Certification Agency or Lembaga Sertifikasi Profesi (LSP) that have met their requirements to obtain competency certification. Competency certification provides certification carried out objectively and systematically through competency tests involving national and international work skills standards. The purpose of awarding certificates is to help professionals ensure and maintain competent workforce capabilities and help customers use competent personnel in the industry. ${ }^{15}$

The Head National Development Planning Agency or Badan Perencanaan Pembangunan Nasional (BAPPENAS) of the Ministry of National Development Planning explained that the implementation of various policies must be optimized, such as providing job training. Only $5 \%$ of employees in Indonesia have received job training. This will also affect the quality and skills of the country's human resources. In addition, the "Labour Law" also establishes a national professional certification body. The national professional certification body can permit the Profession Certification Agency or Lembaga Sertifikasi Profesi (LSP) to obtain competency certification in various government and private fields and must pay serious attention to this. This is a shared responsibility between the government and the private sector. In solving problems such as lack of budget, lack of awareness related to job skills training, and others, the government or the private sector has an important role that is so

\footnotetext{
${ }^{14}$ Ahmad Setiadi, "Strategi Peningkatan Keunggulan Kompetitif SDM Bidang Tik Di Era MEA," Cakrawala: Jurnal Humaniora 16, no. 1 (2016), https://doi.org/10.31294/jc.v16i1.1274.

15 Muhammad Findi Alexandi, "Penyerapan Tenaga Kerja Pada Sektor Pertanian Dan Sektor Jasa Pascakebijakan Upah Minimum Di Provinsi Banten (Periode Tahun 2001-2011)," Journal of Management \& Agribusiness (JMA) 10, no. 2 (2013): 71-80, https://doi.org/10.17358/jma.10.2.71-80.
} 
needed. These problems are a shared responsibility between the government and the private sector so that problems can be resolved, especially job skills training. ${ }^{16}$

BNSP and LSP can help service users to ensure that they use a competent and ready workforce in Indonesia that is competitive in the global job market. Given the implementation of the free movement of employment will not belong. Therefore, various policies that support the improvement of the quality of human resources in the human resources department require optimization in their implementation. ${ }^{17}$ AEC should be an excellent opportunity for Indonesian workers to find work because the presence of the AEC will open up other countries in Southeast Asia to accept workers from Indonesia. For entrepreneurs, AEC can be a way to recruit quality workers to increase their company's value further. Of course, it is hoped that the quality of the output will increase.

However, it should be underlined that the AEC can pose risks that impact employment in Indonesia. Employment competition is something to keep an eye on. Employers want professional people who are experts in their fields. Unfortunately, Indonesia is still inferior to workers from Malaysia, Singapore, and Thailand in terms of education and productivity. Education is regarded as critical and strategic for human resource development. ${ }^{18}$ The quality that has not been able to compete with workers from other countries can cause problems. It should be noted that most Indonesian workers are still low-educated. The lack of education access and the increasing cost every year is the root of the problem that needs to be solved.

\section{Conclusion}

AECs employment arrangements in Indonesia integrate the ASEAN regional economy and one of the ASEAN Community pillars, which aims to achieve this goal by 2015. One of the consequences of implementing the 2015 ASEAN Economic Community is free movement. Skilled workers are defined in the ASEAN Economic Community Blueprint. Government policies already exist, which require human resources to prepare and produce a skilled and high-quality workforce in response to the 2015 AEC. For example, the "Manpower Law" stipulates that workers must be provided with vocational training to improve their skills and qualifications. BNSP and LSP can help service users to ensure that they use a competent and ready workforce in Indonesia that is competitive in the global job market. Therefore, various policies that support the improvement of the quality of human resources in the human resources department require optimization in their implementation. Given the implementation of the free movement of employment will not belong. AEC should be an excellent opportunity for Indonesian workers to find work because the presence of the AEC will open up other countries in Southeast Asia to accept workers from Indonesia. For entrepreneurs, AEC can be a way to recruit quality workers to increase their company's value further. It is hoped that the quality of the output will increase.

\section{REFERENCES}

Adhariani, Desi, Sylvia Veronica Siregar, and Rini Yulius. "Borderless with Unequal Opportunity? Experts' Perspectives on the ASEAN Economic Community and Impact on Indonesian Accountant Profession." The Qualitative Report 24, no. 5 (2019): 1148.

\footnotetext{
${ }^{16}$ Nur Aksin, "Upah Dan Tenaga Kerja (Hukum Ketenagakerjaan Dalam Islam),” Jurnal Meta-Yuridis 1, no. 2 (2018), https://doi.org/10.26877/m-y.v1i2.2916.

${ }^{17}$ Hilman Nur, "Peluang Dan Ancaman Masyarakat Ekonomi Asean (MEA) Bagi Perkembangan Hak Kekayaan Intelektual Indonesia," Jurnal Hukum Mimbar Justitia (JHMJ) 3, no. 2 (2017), https://doi.org/10.35194/jhmj.v3i2.217.

18 Imron Arifin and Agustinus Hermino, "The Importance of Multicultural Education in Schools in the Era of ASEAN Economic Community," Asian Social Science 13, no. $4 \quad$ (2017): 79, https://doi.org/10.5539/ass.v13n4p78.
} 
https://doi.org/10.46743/2160-3715/2019.3940.

Aksin, Nur. "Upah Dan Tenaga Kerja (Hukum Ketenagakerjaan Dalam Islam)." Jurnal MetaYuridis 1, no. 2 (2018). https://doi.org/10.26877/m-y.v1i2.2916.

Alexandi, Muhammad Findi. "Penyerapan Tenaga Kerja Pada Sektor Pertanian Dan Sektor Jasa Pascakebijakan Upah Minimum Di Provinsi Banten (Periode Tahun 2001-2011)." Journal of Management \& Agribusiness (JMA) 10, no. 2 (2013): 71-80. https://doi.org/10.17358/jma.10.2.71-80.

Anshori, Zulkifli, and I Made Suparta. "Pengaruh Pertumbuhan Ekonomi, Jumlah Angkatan Kerja, Dan Inflasi Terhadap Tingkat Pengangguran Di Provinsi Jawa Timur (20072016)." Jurnal Ekonomi \& Bisnis 3, no. $2 \quad$ (2018): 679. https://doi.org/10.1234/jeb17.v3i02.2129.

Arifin, Imron, and Agustinus Hermino. "The Importance of Multicultural Education in Schools in the Era of ASEAN Economic Community." Asian Social Science 13, no. 4 (2017): 79. https://doi.org/10.5539/ass.v13n4p78.

Astuti, Setyani Agung Dwi. "Dampak Covid-19 Terhadap Ketenagakerjaan Dan UMKM Di Mojokerto." Jurnal Inovasi Penelitian 1, no. 9 (2021). https://doi.org/10.47492/jip.v1i9.236.

Destiningsih, Rian. "Pengaruh Sektor Industri Terhadap Peningkatan Tenaga Kerja Di Kabupaten Magelang." Jurnal Humaniora : Jurnal Ilmu Sosial, Ekonomi Dan Hukum 4, no. 2 (2020). https://doi.org/10.30601/humaniora.v4i2.1070.

Haryati, Vivi Regina. "Implementasi Masyarakat Ekonomi Asean Terhadap Elemen Tenaga Kerja Terdidik Di Indonesia." Jurnal Ekonomi Pembangunan 17, no. 2 (2019). https://doi.org/10.29259/jep.v17i2.9508.

Husnayetti. "Masyarakat Ekonomi Asean 2015 Dan Daya Saing Sumber Daya Manusia." Jurnal Liquidity 3, no. 2 (2014). https://doi.org/10.32546/lq.v3i2.94.

Ismail, Najmi. "Hukum Dan Fenomena Ketenagakerjaan.” Focus: Jurnal Pekerjaan Sosial 1, no. 3 (2018). https://doi.org/10.24198/focus.v1i3.20494.

Maulidiah, Sri. “Administrasi Ketenagakerjaan Di Kota Pekanbaru.” Jurnal Publika 1, no. 2 (2015). https://doi.org/10.25299/jiap.2015.vol1(2).1562.

Nikomborirak, Deunden. "The ASEAN Economic Community (AEC): Myths and Realities." Asian Economic Papers 14, no. 2 (2015): 73. https://doi.org/10.1162/ASEP_a_00348.

Nur, Hilman. "Peluang Dan Ancaman Masyarakat Ekonomi Asean (MEA) Bagi Perkembangan Hak Kekayaan Intelektual Indonesia." Jurnal Hukum Mimbar Justitia (JHMJ) 3, no. 2 (2017). https://doi.org/10.35194/jhmj.v3i2.217.

Putra, Anditya. "Implementasi Kebijakan Ketenagakerjaan Di Kabupaten Sumedang." Prosiding Penelitian Dan Pengabdian Kepada Masyarakat 2, no. 3 (2015). https://doi.org/10.24198/jppm.v2i3.13595.

Sahlan. "Preparation of International Business Contracts in Facing the ASEAN Economic Community Era." Hasanuddin Law Review 2, no. 3 (2016): 426. https://doi.org/10.20956/halrev.v2i3.702.

Setiadi, Ahmad. "Strategi Peningkatan Keunggulan Kompetitif SDM Bidang Tik Di Era 
MEA." Cakrawala: Jurnal Humaniora 16, no. 1 (2016). https://doi.org/10.31294/jc.v16i1.1274.

Tobari, Muhammad Kristiawan, and Nova Asvio. "The Strategy Of Headmaster On Upgrading Educational Quality In Asean Economic Community (AEC) Era." International Journal of Scientific \& Technology Research 7, no. 4 (2018): 72.

Yuli, Yuliana. "Regulasi Pendidikan Nasional Sebagai Upaya Meningkatkan Sumber Daya Manusia Memasuki Era Masyarakat Ekonomi Asean (MEA)." Jurnal Yuridis 3, no. 1 (2016). https://doi.org/10.35586/.v3i1.171. 
